\title{
Molecular identification, abundance and distribution of the coral-killing sponge Terpios hoshinota in Bengkulu and Seribu Islands, Indonesia
}

\author{
RISNITA TRI UTAMI, NEVIATY P. ZAMANI, HAWIS H. MADDUPPA ${ }^{\text {}}$ \\ Department of Marine Science and Technology, Faculty of Fisheries and Marine Sciences, Institut Pertanian Bogor. Marine Center Building, Jl Agatis \\ No. 1, Bogor 16680, West Java, Indonesia. Tel.: +62-251-8622-907, Fax.: +62-251-8622-909. "email: hawis@apps.ipb.ac.id.
}

Manuscript received: 27 September 2018. Revision accepted: 10 November 2018

\begin{abstract}
Utami RT, Zamani NP, Madduppa HH. 2018. Molecular identification, abundance and distribution of the coral-killing sponge Terpios hoshinota in Bengkulu and Seribu Islands, Indonesia. Biodiversitas 19: 2238-2246. Coral killing sponge Terpios hoshinota is one of threats to coral reefs. The outbreaks of $T$. hoshinota has been reported in the Indo-Pacific region. However, the current distribution of this species in Western of Sumatera Island is unknown, compared to Seribu Islands. This study aimed to identify coralkilling sponge molecularly and to compare the distribution and abundance of T. hoshinota in Bengkulu (Western of Sumatera) and in Seribu Islands (Northern of Java Island) and to record the preferences of coral substrate of T. hoshinota. Coral reefs and T. hoshinota data were collected using underwater photo transect method with $0.5 \times 0.5 \mathrm{~m}^{2}$ quadrate transect. Coral reefs covered by $T$. hoshinota was analyzed by using Correspondence Analysis, while the determination of biophysical and chemical environment was analyzed by Principal Component Analysis. The identity of the sponge was T. hoshinota. T. hoshinota has been expanding in many reefs across Indonesia especially in Tikus Island and Belanda Island. The most prevalent coral genera in the Seribu Islands infected by T. hoshinota was Acropora while those in Bengkulu were Porites and Pocillopora. Pearson correlation between the live coral cover and T. hoshinota cover was revealed not significant, while $T$. hoshinota cover and orthophosphate was significant. This study suggests that orthophosphate may play a role invasion of T. hoshinota outbreaks.
\end{abstract}

Keywords: invasive sponge, urban reefs, DNA barcoding, correspondent analysis, principal component analysis

\section{INTRODUCTION}

Coral reefs are marine ecosystems formed by the structure of calcium carbonate secreted by coral. Most coral reefs are built by rocky corals consisted of grouped polyps. Most coral reefs can grow in warm, shallow and clear waters. Even though coral reefs occupy less than $0.1 \%$ of the sea level in the world, they provide homes for at least $25 \%$ of all marine species, including fish, mollusks, worms, crustaceans, echinoderms, sponges, tunicates and other cnidarians (Spalding and Grenfell 1997; Spalding et al. 2001; Mulhall 2009). However, coral reefs have been damaged around $20 \%$ over the past few decades in the world (Wilkinson 2004, Wilkinson 2008, Goatley and Bellwood 2011). While the condition of coral reefs in Indonesia according to Giyanto et al. (2017) has a very good status in which only $6.39 \%$ and $35.15 \%$ in poor conditions. The coral reef damage is caused by the increasing human pressure, the use of destructive fishing gear, the increased pollution, the global climate change that causes coral bleaching, as well as coral disease and predation (Wilkinson 2004).

Terpios hoshinota is one of the killer sponges that attack coral reef ecosystem. This sponge belongs to the Porifera Phylum with the Demospongiae Class. This sponge has a very thin tissue $(\leq 1 \mathrm{~mm})$, encrusting, black or dark brown and usually grayish in shallow water. It can grow quickly both on living and on dead corals, which is living in waters along with several types of cyanobacteria in a symbiotic manner (Rützler and Muzik 1993). Terpios hoshinota is known as a strong competitor for coral reefs to grow and live because it can envelop and cover live corals. Moreover, it causes damage and even death to live corals (Bryan 1973; Plucer-Rosario 1987; Wang et al. 2015). T. hoshinota is firstly identified in Tokunoshima Island, Japan (Rützler and Muzik 1993). The first record found that $T$. hoshinota attacked Guam Mariana Islands and American Samoa (Bryan 1973; Plucer-Rosario 1987) and then some records stated it also attacked coral in Green Island, Taiwan (Liao et al. 2007); Lizard Island, Australia (Fujii et al. 2011); Okinoerabu Island, Japan (Reimer et al. 2011a; 2011b); Yongxing Island, South China Sea (Shi et al. 2012); Tioman Island and Peninsular, Malaysia (Hoeksema et al. 2014); Maldives (Montano et al. 2015); Mauritius (Elliot et al. 2016) and Taiping Island, Taiwan (Yang et al. 2018). T. hoshinota are found in several regions in Indonesia, including Seribu (Thousand) Islands, Jakarta; Spermonde Islands, South Sulawesi; Riau Islands; Banten Bay, West Java; Balikpapan Bay, East Kalimantan; and Babar Island, South Maluku (de Voogd et al. 2013; van der Ent et al. 2016; Madduppa et al. 2017).

The condition of coral reefs in the Belanda Island and Dapur Island, part of the Seribu Islands is often associated with anthropogenic activity, sedimentation and climate change (Rachello-Dolmen and Cleary 2007; Fadilah and Idris 2009). However, information about the influence of coral reef conditions in the area of $T$. hoshinota is limited. Many studies related to this had not to be done in 
Indonesia, especially in the Dua Island (Enggano) and Tikus Island, Bengkulu and the Belanda and Dapur Island, Seribu Islands, Jakarta. Therefore, this study aimed to identify $T$. hoshinota based on molecular analysis; analyze abundance of $T$. hoshinota and describe distribution of $T$. hoshinota and aquatic habitat characteristic.

\section{MATERIALS AND METHODS}

\section{Study area and data collection}

The study was conducted in different four locations namely Dua Island, Tikus Island, Dapur Island, and Belanda Island. The Dua (Enggano) and Tikus Islands are located in Bengkulu, while the Dapur and Belanda Island are part of Seribu Islands, Jakarta (Figure 1). Belanda Island belongs to the region of North Seribu Islands District and it is a core coral reef preservation zone, while Dapur Island is included in the South Seribu Islands District and it is currently submerged due to sea sand exploitation (BPS 2017a; BPS 2017b). The Enggano Island is one of the most populous outer islands located in the Indian Ocean (BPS 2017c), while the Tikus Island is located in west of Bengkulu City at a distance of $10 \mathrm{~km}$ from the center of Bengkulu City and it is directly connected to the Indian Ocean (BPS 2018). This research was divided into two zones, namely the inshore zone which was less than $20 \mathrm{~km}$ from the mainland and offshore zone with a distance of more than $60 \mathrm{~km}$ from the mainland.

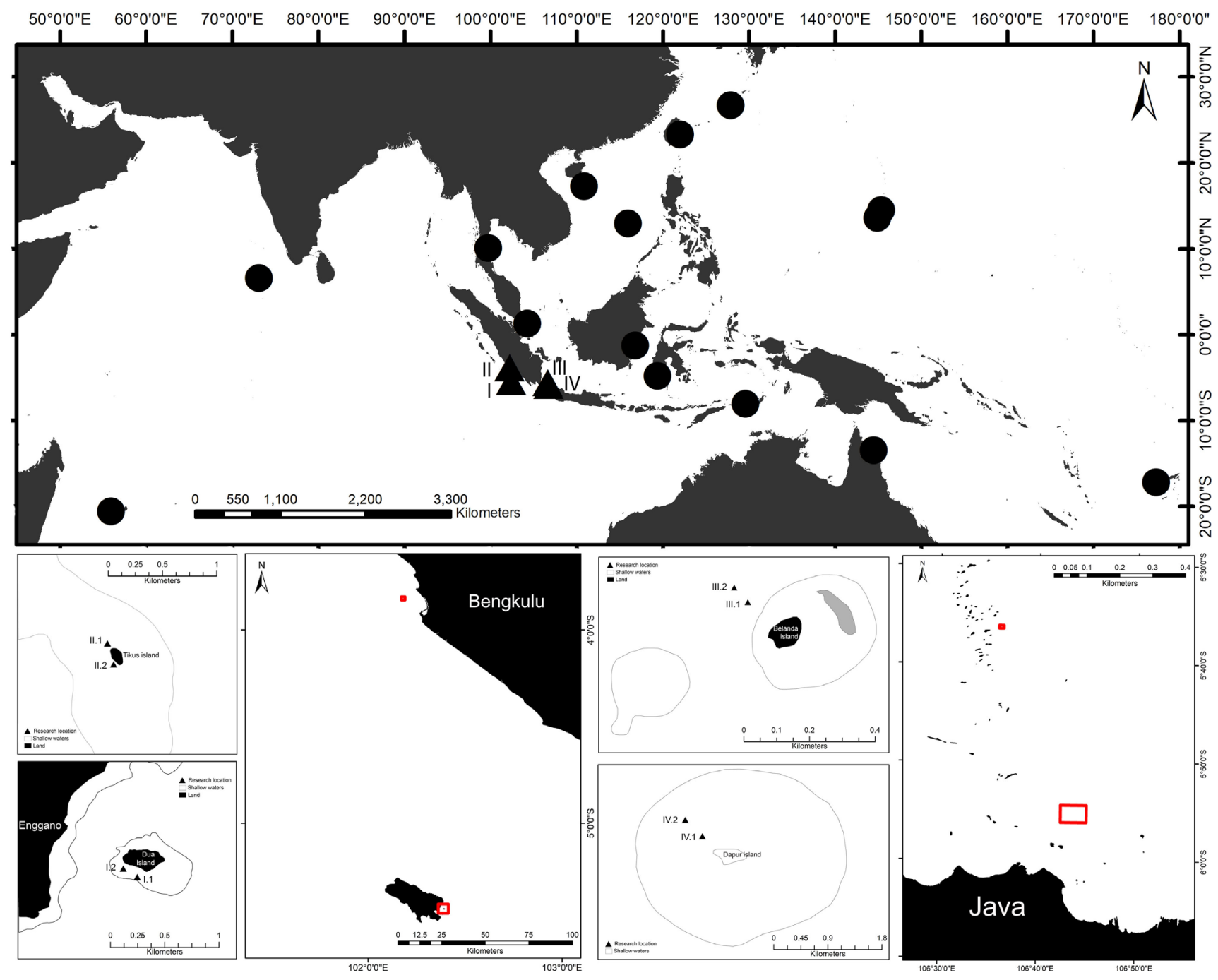

Figure 1. Research location of coral-killing sponge Terpios hoshinota at small islands in Indonesia. ( $\mathbf{\Delta}$ ): I. Dua Island, Enggano; II. Tikus Island; III. Belanda Island and IV. Dapur Island. Location covered by Terpios hoshinota $(\bullet)$ reported by other studies 
Data collection was carried out from January to February 2018 in the coral reefs ecosystem. A total of 8 observation points, spread over 4 islands at small island in Indonesia, were thoroughly surveyed by scuba diving for the presence of $T$. hoshinota. The sessile benthic community of the surveyed reefs and patches of $T$. hoshinota were collected using the UPT (Underwater Photo Transect) method with a $0.5 \times 0.5 \mathrm{~m}^{2}$ transect area (Giyanto et al. 2014). The observation was carried out at two observation points. At each observation point $50 \mathrm{~m}$ transect were laid down, at $\leq 5 \mathrm{~m}$ and $\leq 10 \mathrm{~m}$ (Seribu Islands) and at $1 \mathrm{~m}$ and $1.5 \mathrm{~m}$ (Bengkulu). Identification of coral genus was based on the Coral Finder guidebook (Kelley 2011) and Suharsono's report (2008). Sponge identification in situ was based on the morphological characteristics given by Rützler and Muzik (1993). Specimen of T. hoshinota were preserved in $96 \%$ ethanol. Tissue was collected to confirm the identity of the encrusting sponge $T$. hoshinota by using DNA analysis.

\section{Molecular identification}

The $T$. hoshinota samples obtained in the field were preserved using $96 \%$ alcohol and put into a sample bottle. Extraction of DNA from a sample of sponge tissue used a Geneaid kit. The primers used in this study were ITS2Fwd (5 'GCA GAC-GAC GGA CAG CCT CA-3') and ITS2Rev (5 'TTT GCA GCA CCC CTC TCAG-3'). The PCR condition was carried out as: 35 cycles, each cycle consisted of pre-denaturation at $94^{\circ} \mathrm{C}$ for 3 minutes denaturation at $94^{\circ} \mathrm{C}$ for 30 seconds, annealing at temperature $53^{\circ} \mathrm{C}$ for 30 seconds, extension at $72^{\circ} \mathrm{C}$ for 30 seconds and final extension at $72^{\circ} \mathrm{C}$ for 10 minutes (Yang et al. 2018). The next stage was electrophoresis started with making agar. The PCR product was inserted into the wells contained in agar. Electrophoresis results were visualized in GelDoc to see the presence of the amplified region. If the product had a positive DNA content, the PCR product could be sequenced to know the order of the ingredients. The DNA sequencing process was carried out by FirstBase sequencing facilities found in Malaysia.

\section{Data analysis}

Molecular analysis

The obtained results of $T$. hoshinota sequencing were then analyzed using the Mega 6.0 (Molecular Evolutionary Genetic Analysis) program (Tamura et al. 2013). The obtained sequence was aligned first using the Clustal W menu contained in the program to know the level of nucleotide diversity. Nucleotide alignment data obtained were then matched to the available data on GenBank at NCBI (National Center for Biotechnology Information).

\section{Abundance of $\mathrm{T}$. hoshinota}

Analysis data of $T$. hoshinota area and coral genus attacked by $T$. hoshinota were based on photos taken using a digital camera of Canon G16 analyzed using a computer and Image J software. Moreover, the Microsoft Excel 2016 software was used for processing displays of graphics data (Abràmoff et al. 2004; Munro 2013).

Distribution of $\mathrm{T}$. hoshinota and aquatic habitat characteristic Analysis of the coral reefs condition was based on photos taken using a digital camera of Canon G16 and analyzed using computers and devices CPCE (Coral Point Count with Excel extensions) software (Kohler and Gill 2006). A total of 30 random point samples was selected for each photo frame and for each point coded according to the code of each category, biota, and substrate at the random point. Furthermore, the percentage of cover for each category, biota, and substrate were calculated for each photo frame using the formula: $\square$

Coral cover percentage $=\frac{\text { number of points on each categories }}{\text { number of random points }} \times 100 \%$

In this study, a descriptive statistical analysis was used to describe the data that corresponded to the actual conditions of the observed location. The obtained data were analyzed by simple calculations using Excel 2016 software, and Xlstat Version 2015.1 Distribution of T. hoshinota composition was analyzed using a multivariate statistical model based on Correspondence Analysis (CA). Whereas, determination of environmental characteristic among observed stations was carried out by multivariate statistical approaches based on the Principal Component Analysis (PCA) (Bengen 2000).

\section{RESULTS AND DISCUSSION}

\section{Molecular identification}

The results of ribosomal DNA sequencing showed that the species of sponge was actually $T$. hoshinota. Moreover, the similarity percentage and Genetic bank sources were shown in Table 1. Based on BLAST analysis in genetic banks, it was known that the percentage of similarity ranging from $96 \%$ to $98 \%$. It means that the similarity of $T$. hoshinota in each observed station was quite high.

Terpios hoshinota is one of the killer sponges that attacks coral reef ecosystems. Figure 2 presents $T$. hoshinota in the observed regions.

Table 1. Identification data of invasive species using BLAST

\begin{tabular}{cccc}
\hline Sample ID $\square$ & BLAST Analysis & $\begin{array}{c}\text { Similarity } \\
(\%)\end{array}$ & $\begin{array}{c}\text { GeneBank } \\
\text { Accession }\end{array}$ \\
\hline ITK_TIK1_SP1 & Terpios hoshinota & 97 & MH048888.1 \\
ITK_DUA1_SP1 & Terpios hoshinota & 98 & MH048888.1 \\
ITK_BLD1_SP1 & Terpios hoshinota & 96 & MH048888.1 \\
ITK_DPR2_SP1 & Terpios hoshinota & 97 & MH048888.1 \\
\hline
\end{tabular}


Table 2. Measurement data of coral reefs area covered by Terpios hoshinota at each point of the study location

\begin{tabular}{|c|c|c|c|c|c|}
\hline \multicolumn{2}{|c|}{ Locality } & Coordinate & $\begin{array}{c}\text { Distance from Bengkulu/ } \\
\text { Jakarta (km) } \\
\end{array}$ & $\begin{array}{c}\text { Depth of } \\
\text { patches (m) }\end{array}$ & $\begin{array}{c}\text { Size of patch } \\
\left(\mathrm{cm}^{2}\right)\end{array}$ \\
\hline Bengkulu & Dua 1 & $5^{\circ} 26^{\prime} 52,44^{\prime \prime} \mathrm{S} 102^{\circ} 23^{\prime} 37,824^{\prime \prime} \mathrm{E}$ & \pm 140 & \pm 1 & 1426.49 \\
\hline & Dua 2 & $5^{\circ} 26^{\prime} 52,44^{\prime \prime} \mathrm{S} 102^{\circ} 23^{\prime} 37,824^{\prime \prime} \mathrm{E}$ & \pm 140 & $\pm 1,5$ & 1355.98 \\
\hline & Tikus 1 & $3^{\circ} 50^{\prime} 12,624 ” \mathrm{~S} 102^{\circ} 11^{\prime} 47,65^{\prime \prime} \mathrm{E}$ & \pm 10 & \pm 1 & 2763.50 \\
\hline & Tikus 2 & $3^{\circ} 50^{\prime} 12,624^{\prime \prime} \mathrm{S} 102^{\circ} 11^{\prime} 47,65^{\prime \prime} \mathrm{E}$ & \pm 10 & $\pm 1,5$ & 1874.07 \\
\hline \multirow[t]{4}{*}{ Seribu Islands } & Belanda 1 & $5^{\circ} 36^{\prime} 13,77^{\prime \prime} \mathrm{S} 106^{\circ} 36^{\prime} 11,00^{\prime \prime} \mathrm{E}$ & \pm 65 & \pm 3 & 2247.77 \\
\hline & Belanda 2 & $5^{\circ} 36^{\prime} 13,77^{\prime \prime} \mathrm{S} 106^{\circ} 36^{\prime} 11,00^{\prime \prime} \mathrm{E}$ & \pm 65 & \pm 6 & 1628.83 \\
\hline & Dapur 1 & $5^{\circ} 55^{\prime} 23,07^{\prime \prime} \mathrm{S} 106^{\circ} 43^{\prime} 21,03$ ” E & \pm 15 & \pm 5 & 880.694 \\
\hline & Dapur 2 & $5^{\circ} 55^{\prime} 23,07^{\prime \prime} \mathrm{S} 106^{\circ} 43^{\prime} 21,03$ ” E & \pm 15 & \pm 8 & 2927.224 \\
\hline Sum & & & & & $15,104.55$ \\
\hline
\end{tabular}
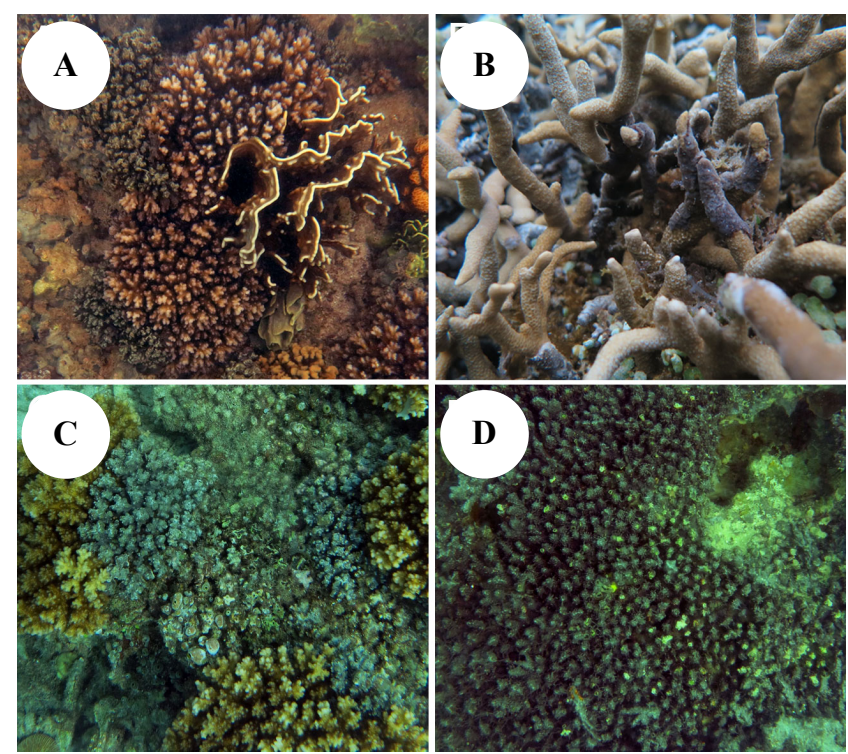

Figure 2. Morphology of Terpios hoshinota. A) Colonies found in the Tikus Island, Bengkulu; B) Colonies found in the Dua Island (Enggano ), Bengkulu C) Colonies found in the Belanda Island, Jakarta; D) Colonies found in the Dapur Island, Jakarta

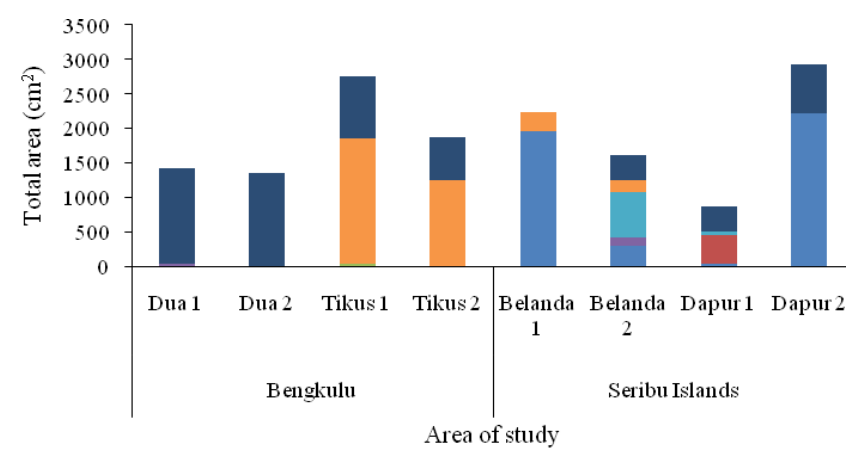

- Porites $\backsim$ Pocillop ora $\backsim$ Montipora $\|$ Gardineroseris $\backsim$ Favia $\|$ Dead Coral $₫$ Acropora

Figure 3. Distribution of coral genus covered by Terpios hoshinota in the coral reef ecosystem

\section{Abundance of Terpios hoshinota}

The total area covered by $T$. hoshinota at the research location was $15,104.55 \mathrm{~cm}^{2}$. The area of coral reefs covered by $T$. hoshinota varied at each station. The highest area covered by T. hoshinota was found in Tikus Island and Belanda Island was $4,637.57 \mathrm{~cm}^{2}$ and $3,876.60 \mathrm{~cm}^{2}$. While the lowest area of coral reefs covered by $T$. hoshinota was found in Dua Island, with an area of $2,782.46 \mathrm{~cm}^{2}$. The result of coral reef area covered by $T$. hoshinota was shown in Table 2.

\section{Distribution of $T$. hoshinota and aquatic habitat characteristic}

Figure 3 shows the total area of the coral genus covered by $T$. hoshinota at the study location. The types of coral covered by $T$. hoshinota at the study location consisted of six genera namely Acropora, Favia, Gardineroseris, Montipora, Pocillopora, and Porites. Belanda Island is the location where the most common species of coral genus covered by T. hoshinota was found which consisted of five genera. While the other one was in Dua Island and Tikus Island with three coral genera in each island. The types of the coral genus found in the Belanda Island were Acropora, Gardineroseris, Montipora, Pocillopora, and Porites. The types of the coral genus found in Dua Island were Acropora, Gardineroseris and Porites, while the genera found in Tikus island were Favia, Pocillopora and Porites.

The results showed that the number of corals predominantly used as a substrate by invertebrates to grow and attach was the genera of Porites, Acropora and Pocillopora compared to other genera. The genera of Porites, Acropora and Pocillopora are the most dominant genera that easy to be attached by invertebrates because they have a gap among coral branches. So, it is easy for invertebrates to live on it.

The spatial distribution of T. hoshinota was shown in Figure 4. This diagram showed that four groups of research stations have linked between observed stations and $T$. hoshinota cover. The first group consisted of the Belanda 1 and Dapur 2 Islands identified by Scleractinia coral with genus of Acropora. The second group was the Belanda 2 identified by Scleractinia coral with a genera Montipora and Gardineroseris. The third group consisted of Dapur 1 Island identified by dead coral. The fourth group was the 
Tikus 1, Tikus 2, Dua 1 and Dua 2 Islands identified by Scleractinia coral with the genera of Favia, Porites, and Pocillopora.

Water quality measurement was done to find out the actual condition of the waters as the research location. The characteristics of the coastal waters of the four research sites were classified as a feasible area for coral reefs to live and grow (Table 3).

Correlation matrix of Pearson at each point of the study location was shown in Table 4. This table showed that $T$. hoshinota has a negative correlation with the percentage of live coral cover, temperature, salinity, $\mathrm{pH}$, ammonia, nitrate, and nitrite. Meanwhile, it has a positive correlation with DO and orthophosphate.

The characteristics of the biophysical conditions of the chemical environment were analyzed by the main component analysis approach called Principal Component Analysis (PCA). It consisted of percentage of live coral cover $(\% \mathrm{Lc})$, Total area of $T$. hoshinota, temperature, salinity, $\mathrm{pH}$, dissolved oxygen (DO), ammonia, nitrate, nitrite, and orthophosphate data. The results indicated that the information describing the correlation among parameters was focussed on the two main axes F1 and F2. The reliance percentage of information quality for two axes were $45.92 \%$ and $19.28 \%$, respectively, so the range of environmental characteristics of Scleractinian corals in the observed station could be explained from the total range of the two main axes that was $65.20 \%$. For more details, could be seen in the diagram (Figure 5). $\square$

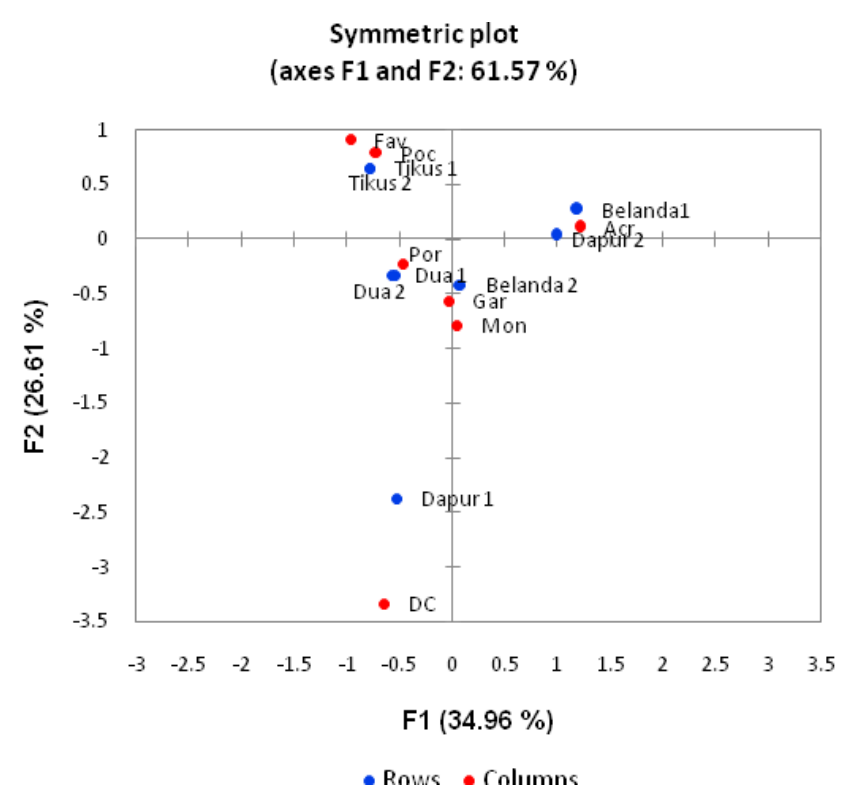

Figure 4. Correspondent analysis of genus invaded by Terpios hoshinota at each station

Table 3. Results of physical-chemical-biological parameters measurement of the waters at each point of the study location

\begin{tabular}{|c|c|c|c|c|c|c|c|c|}
\hline \multirow{2}{*}{ Parameters } & \multicolumn{4}{|c|}{ Bengkulu } & \multicolumn{4}{|c|}{ Seribu Islands, Jakarta } \\
\hline & Dua 1 & Dua 2 & Tikus 1 & Tikus 2 & Belanda 1 & Belanda 2 & Dapur 1 & Dapur 2 \\
\hline Percentage of live coral cover (\%) & 38.27 & 36.27 & 39.67 & 66.73 & 31.80 & 26.47 & 17.67 & 15.53 \\
\hline Total area of T. hoshinota $\left(\mathrm{cm}^{2}\right)$ & 1426.49 & 1355.98 & 2763.50 & 1874.07 & 2247.77 & 1628.83 & 880.69 & 2927.22 \\
\hline Temperature $\left({ }^{\circ} \mathrm{C}\right)$ & 28.8 & 28.7 & 28.3 & 28.3 & 29.4 & 29.3 & 29.1 & 29.1 \\
\hline Salinity (psu) & 34.6 & 34.6 & 32.2 & 32.2 & 31.8 & 31.8 & 29.1 & 29.2 \\
\hline $\mathrm{pH}$ & 8.3 & 8.4 & 8.1 & 8.3 & 8.3 & 8.4 & 8.2 & 8.4 \\
\hline $\mathrm{DO}(\mathrm{mg} / \mathrm{L})$ & 7.6 & 7.2 & 7.4 & 7.6 & 6.8 & 6.6 & 7.6 & 7.8 \\
\hline Ammonia (mg/L) & 0.085 & 0.034 & 0.037 & 0.045 & 0.183 & 0.174 & 0.311 & 0.221 \\
\hline Nitrate $(\mathrm{mg} / \mathrm{L})$ & 0.071 & 0.071 & 0.071 & 0.065 & 0.072 & 0.087 & 0.098 & 0.08 \\
\hline Nitrite (mg/L) & 0.004 & 0.004 & 0.005 & 0.004 & 0.006 & 0.007 & 0.006 & 0.005 \\
\hline Orthophosphate (mg/L) & 0.004 & 0.004 & 0.007 & 0.004 & 0.003 & 0.005 & $<0.002$ & 0.006 \\
\hline
\end{tabular}

Note: * Ammonia Quality Standard $0.3 \mathrm{mg} / \mathrm{L}$; Nitrate 0.008; Orto Phosphate $0.015 \mathrm{mg} / \mathrm{L}$ (Ministry of Environment Decree 512004 )

Table 4. Correlation matrix of Pearson at each point of the study location

\begin{tabular}{|c|c|c|c|c|c|c|c|c|c|c|}
\hline Variables & $\%$ Lc & Temperature & Salinity & pH & DO & Ammonia & Nitrate & Nitrite & $\begin{array}{c}\text { Ortho } \\
\text { phosphate }\end{array}$ & $\begin{array}{c}T . \\
\text { hoshinota }\end{array}$ \\
\hline$\% \mathrm{Lc}$ & 1 & -0.737 & 0.543 & -0.156 & 0.077 & -0.771 & -0.762 & -0.577 & 0.040 & -0.003 \\
\hline Temperature & -0.737 & 1 & -0.384 & 0.442 & -0.486 & 0.763 & 0.586 & 0.727 & -0.385 & -0.133 \\
\hline Salinity & 0.543 & -0.384 & 1 & 0.136 & -0.230 & -0.813 & -0.669 & -0.543 & 0.043 & -0.235 \\
\hline $\mathrm{pH}$ & -0.156 & 0.442 & 0.136 & 1 & -0.250 & 0.058 & -0.025 & 0.000 & -0.084 & -0.093 \\
\hline DO & 0.077 & -0.486 & -0.230 & -0.250 & 1 & 0.008 & -0.064 & -0.632 & 0.089 & 0.102 \\
\hline Ammonia & -0.771 & 0.763 & -0.813 & 0.058 & 0.008 & 1 & 0.862 & 0.675 & -0.427 & -0.174 \\
\hline Nitrite & -0.577 & 0.727 & -0.543 & 0.000 & -0.632 & 0.675 & 0.702 & 1 & -0.109 & -0.028 \\
\hline Orthophosphate & 0.040 & -0.385 & 0.043 & -0.084 & 0.089 & -0.427 & -0.318 & -0.109 & 1 & 0.765 \\
\hline T. hoshinota & -0.003 & -0.133 & -0.235 & -0.093 & 0.102 & -0.174 & -0.398 & -0.028 & 0.765 & 1 \\
\hline
\end{tabular}




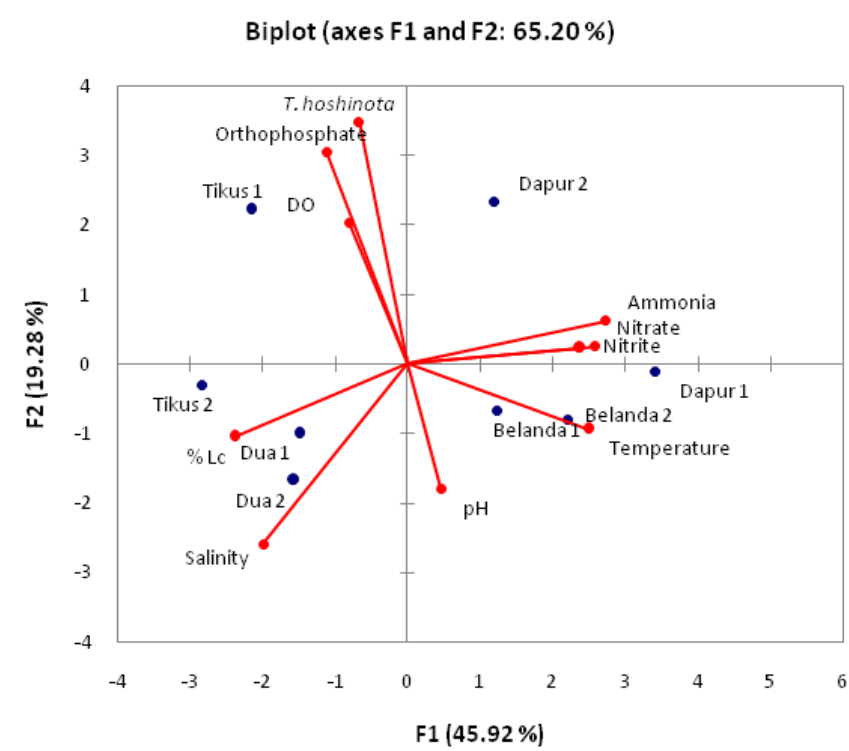

Figure 5. Principal Component Analysis between chemical biophysical parameters and the distribution of research stations on the F1 and F2 axes

Based on the circular diagram, the intersection between the axes F1 and F2 (Figure 5) showed that there was a correlation among temperature, ammonia, nitrate, nitrite, and percentage of live coral cover forming a positive F1 axis, while salinity contributed to forming a negative F1 axis. Orthophosphate and T. hoshinota contributed to forming a positive $\mathrm{F} 2$ axis.

The diagram of main component analysis formed three station distribution groups based on their relationship to environmental biophysical characteristics. The first station group consisted of the Dapur 1, the Belanda 1 and the Belanda 2 Islands where the station was characterized by a high concentration of ammonia, nitrate, nitrite, and temperature compared to other stations. The high concentration of ammonia and nitrate in seawater at the study site came from the river flow from the mainland of Java entering the Jakarta Bay. The distance of the study location to the Jakarta bay ranged $\pm 15 \mathrm{~km}$, so the proximity of the study location allowed the increase of nutrients in the Dapur Island water. The concentration of nitrite and the value of temperatures on the Dapur 1, the Belanda 1 Island and the Belanda 2 Island were still categorized as optimum conditions for coral growth. The second group consists of the Dua 1 Island and the Tikus 2 Island characterized by their salinity and percentage of live coral cover. Salinity concentration at this station is still at the optimum limit for coral reef to grow. While the third group consisted of the Dapur 2 Island and Tikus 1 Island identified by Orthophosphate and T. hoshinota.

\section{Discussion}

The current study has confirmed the species of $T$. hoshinota using molecular approach. Molecular techniques have become essential tools for identification of marine species (Madduppa et al. 2014; Prehadi et al. 2015;
Kusuma et al. 2016; Maulid et al. 2016). The ITS region of the ribosomal DNA has been used to distinguish genera and species of a wide range of demosponge taxa. The examination of ribosomal DNA sequences confirmed that the identity of sponge was T. hoshinota. All sequences were submitted to NCBI GenBank under accession number MH048888.1. The ITS sequence of T. hoshinota obtained from GenBank, originates from Taiping Island, South China Sea, where the sponge has had outbreak event in 2017 (Yang et al. 2018).

In the present study, T. hoshinota was observed in many reefs across Indonesia. Eight patches of T. hoshinota were found varying in size between $880.694 \mathrm{~cm}^{2}$ and 2927.224 $\mathrm{cm}^{2}$ and a total cover of $15,104.55 \mathrm{~cm}^{2} . T$. hoshinota was most abundant on the reef of Tikus Island (distance from Bengkulu $10 \mathrm{~km}$ ) and Belanda Island (distance from Jakarta $65 \mathrm{~km}$ ). These findings are supported by a survey Spermonde Archipelago (van der Ent et al. 2016), where $T$. hoshinota was also found at various locations across the shelf. It indicated that $T$. hoshinota has been observed in all different environments and spatially.

All live coral substrates were identified to genera level. $T$. hoshinota patches were mostly found on corals of the family Acroporidae, Poritidae and Pocilloporidae. Correspondence Analysis (CA) showed that the the most prevalent coral genera infected by $T$. hoshinota in Belanda 1 and Dapur 2 Islands was Acropora (Acroporidae), while those in Bengkulu were Porites (Poritidae) and Pocillopora (Pocilloporidae). Multiple studies on T. hoshinota have been carried out in various countries including research conducted by Liao et al. (2007) and Tang et al. (2011) in Green Island, Taiwanese. The research study found that the common genera infected by T. hoshinota were Montipora, Acropora, Isopora, Millepora, Favia and Porites. In addition, van der Ent et al. (2016) figured out that the infected genera in the Spermonde Islands, South Sulawesi were Acropora, Isopora, Montipora, Pocillopora, Seriatopora and Pavona. However, according to Wang et al. (2012), there was no specific coral reef species that could be infected by T. hoshinota.

Various studies on the distribution and condition of coral reefs in the Seribu Islands were widely carried out (Cleary et al. 2006; Rachello-Dolmen and Cleary 2007; Johan et al. 2012; Madduppa et al. 2012). The eight observation points where patches of $T$. hoshinota were discovered also varied distinctly from each other in benthic community structure. T. hoshinota were found at sites with good, fair and poor cover of live corals. It indicated that $T$. hoshinota can survive within different benthic community structures. These findings are supported by a survey of Ryukyu Archipelago (Reimer et al. 2011) and Spermonde Archipelago (van der Ent et al. 2016), where T. hoshinota was also found in pure reefs, as well as reefs that increasing human pressure. However, the present study showed no large variation in patch size between the eight observation points where $T$. hoshinota was observed. $T$. hoshinota outbreaks are probably not related to variation in benthic community structure.

The highest area covered by T. hoshinota was found in Tikus Island and Belanda Island. Belanda Island has poor 
water quality with high nutrient concentrations. Cleary et al. (2006) stated that the location of coastal waters was around $15-50 \mathrm{~km}$ influenced by fishing activities. In addition, it has poor water quality with high nutrient concentrations. During the dry season, the southeast wind blows, so that the flow of nutrients from the Jakarta Bay River flows to the Seribu Islands. The high level of nutrients in the water where coral reefs live and grow caused the fertile proliferation of algae and sponges which led to space competition (Cleary et al. 2006; Fadilah and Idris 2009; Madduppa et al. 2013; Fahlevy et al. 2018). As in Guam, T. hoshinota was found in polluted areas and the area experiences stress caused by coastal development (Plucer-Rosario 1987; Rützler and Muzik 1993). However, the lowest area covered by T. hoshinota was found in Dua Island, Enggano. Enggano Island is one of the outer Islands and far away from human activity. Dua Island has a clean aquatic environment quality remains infected by $T$. hoshinota. Similar situations were found in Green Island, Taiwan and Yonxing Island (Shi et al. 2012). An area located far away from human activity has a good water quality, however; it is also infected by T. hoshinota.

Coral reef degradation is a significant problem in the world. Competition among sessile organisms is one of the main ecological processes in coral reefs ecosystem and it can lead to changes in the diversity and abundance of coral species at spatial and temporal scales (Connel et al. 2004; Chadwick and Morrow 2011). Sponges are sessile organisms defending themselves by using chemicals. It causes them to become natural predators or parasites and they do this as an ecological function (Proksch 1994; Laport et al. 2009). T. hoshinota is a threat to coral reefs in Indo-Pacific Ocean. T. hoshinota make a symbiotic interaction with various microorganisms, such as bacteria and fungi (Bryan 1973; Plucer-Rosario 1987; Rützler and Muzik 1993; Hirose and Murakami 2011). Cyanobacteria have a very dense population on the spongy tissue. The composition of cyanobacteria in $T$. hoshinota sponges reaches 61\% - 98\% (Rützler and Muzik 1993; Hirose and Murakami 2011; Tang et al. 2011) and cyanobacterial photosynthesis are responsible for nutrient sources for $T$. hoshinota (Rützler and Muzik 1993; Soong et al. 2009). Some of these compounds are important in sponge ecological adaptations (Faulkner et al. 1994; Kobayashi and Kitagawa 1994; Guyot 2000; Proksch et al. 2003; Thakur and Möller 2004). The symbiosis between $T$. hoshinota and cyanobacteria helps T. hoshinota to be more competitive to attack coral reefs spatially and grow to cover coral reefs (Plucer-Rosario 1987).

In the current study, Principal Component Analysis (PCA) showed that at Belanda 1, Belanda 2 and Dapur 1 Islands, temperature, ammonia, nitrate and nitrite has high environmental characteristics correlation. At Dua 1 and Tikus 2 Islands, salinity and percentage of live coral cover have high environmental characteristics correlation. Meanwhile, at Tikus 1 and Dapur 2 Islands, orthophosphate has high environmental characteristics correlation. The result of the Pearson correlation between the live coral cover and $T$. hoshinota cover showed a negative linear relationship. It indicated that the higher live coral cover, the lower T. hoshinota cover. But the value was not significant $(-0.003)$.

Meanwhile, the result of the Pearson correlation between T. hoshinota cover and orthophosphate showed that positive linear relationship. This is indicated that the higher the orthophosphate, the higher T. hoshinota cover. The value was significant $(0.765)$.

The cause of the spread of $T$. hoshinota was not yet clearly known. It was expected that the cause of the spreading $T$. hoshinota is due to environmental factors including availability of nutrients, host specificity, coral cover, ocean currents, and others (Shi et al. 2012). $\mathrm{Ng}$ et al. (2012) suspected that the increased concentrations of iron, phosphate, and nitrite lead to the blooming of cyanobacteria found in T. hoshinota. Meanwhile, according to Schils (2012), T. hoshinota infection was not only due to chemical components, but it might also due to human activities such as the sinking of the ship, burning forest and storm. Moreover, Averts (2000) suspected that the health of coral reefs might affect $T$. hoshinota infection. According to Elliot et al. (2016), there are three possibilities for $T$. hoshinota to attack coral reefs. First, T. hoshinota grow up covering the coral and rapidly expand to cover the coral. Second, the presence of allelopathic compounds that is able to produce cytotoxic compounds produced by sponges (Teruya et al. 2004). The last possibility is the presence of a bacterial community caused $T$. hoshinota to be more aggressive in killing corals (Wang et al. 2012; Tang et al. 2011).

This study concludes that the Coral-killing sponge $T$. hoshinota has been expanding in many reefs across Indonesia. T. hoshinota was most abundant on the reef of Tikus Island and Dapur Island. The most prevalent coral genera in the Seribu Islands infected by T. hoshinota was Acropora (Acroporidae) while those in Bengkulu were Porites (Poritidae) and Pocillopora (Pocilloporidae). Pearson correlation between the live coral cover and $T$. hoshinota cover was not significant, while $T$. hoshinota cover and orthophosphate was significant. This study suggests that orthophosphate may play a role invasion of T. hoshinota outbreaks.

\section{ACKNOWLEDGEMENTS}

We would like to thank the Seribu Island National Park Office for grant permission for this research. Thanks to Rafflesia Bengkulu Diving Club; Marine Science and Technology Diving School; and Marine Biodiversity and Biosystematics Laboratory, Marine Science and Technology, Institut Pertanian Bogor (IPB) which has facilitated the completion of this research.

\section{REFERENCES}

Abràmoff MD, Magalhães PJ, Ram SJ. 2004. Image processing with image J Biophotonics Intl 11 (7): 36-41.

BPS-Statistics of Kepulauan Seribu Regency. 2017a. Kepulauan Seribu Utara in figures 2017, Jakarta. [Indonesian] 
BPS-Statistics of Kepulauan Seribu Regency. 2017b. Kepulauan Seribu Selatan in figures 2017, Jakarta. [Indonesian]

BPS-Statistics of Bengkulu Utara Regency. 2017c. Kecamatan Enggano in figures 2017, Bengkulu. [Indonesian]

BPS-Statistics of Bengkulu Municipality. 2018. Bengkulu Municipality in figures 2018, Bengkulu. [Indonesian]

Averts LAM. 2000. Dynamics behind standoff interactions in three reef sponge species and the coral Montastrea cavernosa. Mar Ecol 21: 191-204.

Bengen DG. 2000. Sinopsis Teknis Pengambilan Contoh dan Analisis Data Biofisik Sumberdaya Pesisir. IPB Press, Bogor.

Bryan PG. 1973. Growth rate, toxicity and distribution of the encrusting sponge Terpios sp. (Hadromerida: Suberitidae) in Guam, Mariana Islands. Micronesica. 9 (2): 237-242.

Chadwick NE, Morrow KM. 2011. Competition among sessile organisms on coral reefs. In: Dubinsky Z, Stambler N (eds) Coral Reefs: An Ecosystem in Transition. Springer, Netherland.

Cleary DFR, Suharsono, Hoeksema BW. 2006. Coral diversity across a disturbance gradient in the Pulau Seribu reef complex off Jakarta, Indonesia. Biodivers Conserv 15: 3653-3674.

Connell JH, Hughes TP, Wallace CC, Tanner JE, Harms KE, Kerr AM. 2004. A long-term study of competition and diversity of corals. Ecol Monogr 74 (2): 179-210.

de Voogd NJ, Cleary DFR, Dekker F. 2013. The coral-killing sponge Terpios hoshinota invades Indonesia. Coral Reefs. 32 (3): 755.

Elliot J. Petterson M, Vitry E, Summers N. 2016. Morphological plasticity allows coral to actively overgrow the aggressive sponge Terpios hoshinota (Mauritius, Southwestern Indian Ocean). Mar Biodiv 46: 489-493.

Fadilah, Idris. 2009. Perbandingan Dua Tahunan Persentase Penutupan Karang di Kepulauan Seribu (2003, 2005, dan 2007). In: Estradivari, Setyawan E, Yusri $S$ (eds) Terumbu Karang Jakarta. Yayasan Terumbu Karang Indonesia (TERANGI), Jakarta.

Fahlevy K, Yudha FK, Andika W, Supriyanto AE, Irianda NJ, Irfanto M, Subhan B, Madduppa HH. 2018. Assessing fish community structure at two different coral reef depths around Seribu Islands, Jakarta. J Ilmu Kelautan Kepulauan 1(1):15-29. [Indonesian]

Faulkner DJ, Unson MD, Bewley CA. 1994. The chemistry of some sponges and their symbionts. Pure and Appl Chem: 66:1983.

Fujii T, Keshavmurthy S, Zhou W, Hirose E, Chen CA, Reimer JD. 2011 Coral Killing cyanobacteriosponge (Terpios hoshinota) on the Great Barrier Reef. Coral Reefs. 30:483.

Giyanto, Manuputty A, Abrar M, Siringoringo R, Suharti S, Wibowo K, Edrus I, Arbi U, Cappenberg H, Sihaloho H. 2014. Panduan Monitoring Kesehatan Terumbu Karang. Suharsono, Sumadhiharga OK (eds). Puslit Oseanografi LIPI Press, Jakarta.

Giyanto, Abrar M, Hadi TA, Budiyanto A, Hafizt M, Salatalohy A, Iswari MY. 2017. Status Terumbu Karang Indonesia 2017. Suharsono (eds). Puslit Oseanografi LIPI Press, Jakarta.

Goatley CHR, Bellwood DR. 2011. The roles of dimensionality, canopies and complexity in ecosystem monitoring. PLoS ONE 6 (11): e27307. DOI: 10.1371 / journal.pone.0027307.

Guyot M. 2000. Intricate aspects of sponge chemistry. Zoosystema. 22 (2): 419-431

Hirose E, Murakami A. 2011. Microscopic Anatomy and Pigment Characterization of Coral-Encrusting Black Sponge with Cyanobacterial Symbiont, Terpios hoshinota. Zool Sci 28 (3): 199205. DOI:10.2108/zsj.28.199.

Hoeksema BW, Waheed Z, de Voogd NJ. 2014. Partial mortality in corals overgrown by the sponge Terpios hoshinota at Tioman Island, Peninsular Malaysia (South China Sea). Bull Mar Sci 90: 989-990.

Johan O, Bengen DG, Zamani NP, Suharsono. 2012. Distribution and Abundance of Black Band Disease on Corals Montipora $s p$ in Seribu Islands, Jakarta. J Indonesia Coral Reefs 1 (3): 160-170. [Indonesian]

Kelley R. 2011. The Indo Pacific Coral Finder 2.0. BYO Guides, Australia.

Kobayashi M, Kitagawa I. 1994. Bioactive substances isolated from marine sponge, a miniature conglomerate of various organisms. Pure Appl Chem 66 (4): 819- 826

Kohler KE, Gill SM. 2006. Coral Point Count with Excel extensions (CPCe): A Visual Basic program for the determination of coral and substrate coverage using random point count methodology. Computers and Geosciences. 32 (9): 1259-1269. DOI:10.1016/j.cageo.2005.11.009.

Kusuma AB, Bengen DG, Madduppa H, Subhan B, Arafat D. 2016 Keanekaragaman genetik karang lunak Sarcophyton trocheliophorum pada populasi Laut Jawa, Nusa Tenggara dan Sulawesi. Jurnal Enggano 1 (1) 89-96. [Indonesian]

Laport MS, Santos OCS, Muricy G. 2009 Marine sponge: potential sources of new antimicrobial drugs. Curr Pharm Biotechnol 10 (1): $86-105$.

Liao MH, Tang SL, Hsu CM, Wen KC, Wu H, Chen WM, Chen CA. 2007. The Black Disease of reef-building corals at Green Island, Taiwan - outbreak of a cyanobacteriosponge, Terpios hoshinota (Suberitidae; Hadromerida). Zool Stud 46 (4): 520

Madduppa HH, Ferse SCA, Aktani U, Palm HW. 2012. Seasonal trends and fish habitat associations around Pari Island, Indonesia: setting a baseline for environmental monitoring. Environ Biol Fishes 95 (3): 383-398.

Madduppa HH, Subhan B, Suparyani E, Siregar A, Arafat M, Tarigan D, Alimuddin, Khairudi D, Rahmawati F, Bramandito A. 2013. Dynamics of fish diversity across an environmental gradient in the Seribu Islands Reefs off Jakarta. Biodiversitas. 1: 17-24.

Madduppa HH, Timm J, Kochzius M. 2014. Interspecific, spatial and temporal variability of self-recruitment in anemonefishes. PLoS One. 9 (6): e101396. DOI: 10.1371/journal.pone.0090648.

Madduppa HH, Schupp PJ, Faisal MR, Sastria MY, Thoms C. 2017. Persistent outbreaks of the black disease sponge Terpios hoshinota in Indonesian coral reefs. Mar Biodiv 47 (1): 149-151. DOI: $10.1007 / \mathrm{s} 1252$

Maulid DY, Nurilmala M, Madduppa H. 2016. Karakteristik molekuler Cytochrome B untuk DNA barcoding ikan tenggiri. Jurnal Pengolahan Hasil Perikanan Indonesia 19 (1): 9-16. [Indonesian]

Ministry of Environment. 2004. Minister of environment decree No. 51 of 2004 concerning sea water quality standards

Montano S, Chou WH, Chen CA, Galli P, Reimer JD. 2015. First record of the coral-killing sponge Terpios hoshinota in the Maldives and Indian Ocean. Bull Mar Sci 91 (1). DOI:10.5343/bms.2014.1054.

Mulhall M. 2009. Saving rainforests of the sea: An analysis of international efforts to conserve coral reefs. Duke Environmental Law and Policy Forum 19: 321-351.

Munro C. Diving. 2013. In Eleftheriou A (eds) Methods for the study of marine benthos, fourth edition. Blackwell Science, Oxford.

Ng CSL, Lin Jin Ong LJ, Chou LM. 2012. Lyngbya majuscula blooms in an enclosed marine environment. Environ Asia 5: 93-98.

Plucer-Rosario G. 1987. The effect of substratum on the growth of Terpios, an encrusting sponge which kills corals. Coral Reefs 5(4): 197-200. DOI:10.1007/BF00300963.

Prehadi, Sembiring A, Kurniasih EM, Rahmad R, Arafat D, Subhan B, Madduppa H. 2015. DNA barcoding and phylogenetic reconstruction of shark species landed in Muncar fisheries landing site in comparison with Southern Java fishing port. Biodiversitas 16 (1): 55-61. DOI:10.13057/biodiv/d160107

Proksch P, Ebel R, Edrada RA, Schuup P, Lin WH, Sudarsono, Wray V. dan Steube K. 2003. Detection of pharmacologically active natural products using ecology. Selected examples from Indopacific marine invertebrates and sponge-derived fungi. Pure and Appl Chem 2003: 75 (Nos 2-3): 343-352.

Proksch P. 1994. Defensive roles for secondary metabolites from marine sponges and sponge-feeding nudibranchs. Toxicon 32: 639-655.

Rachello-Dolmen PG, Cleary DFR. 2007. Relating coral traits to environmental conditions in the Jakarta Bay / Pulau Seribu reef complex, Indonesia. Estuarine, Coastal and Shelf Science 73: 816826.

Reimer JD, Mizuyama M, Nakano M, Fujii T, Hirose E. 2011a. Current status of the distribution of the coral-encrusting cyanobacteriosponge Terpios hoshinota in southern Japan. Galaxea, J Coral Reef Stud. 13:35-44.

Reimer JD, Y Nozawa, E Hirose. 2011b. Domination and disappearance of the black sponge: a quarter century after the initial Terpios outbreak in southern Japan. Zool Stud 50 (3): 394.

Rützler K, Muzik K. 1993. Terpios hoshinota, a new cyanobacteriosponge threatening Pacific reefs. Sci Mar 57 (4): 395-403.

Schils T. 2012. Episodic Eruptions of Volcanic Ash Trigger a Reversible Cascade of Nuisance Species Outbreaks in Pristine Coral Habitats. PLoS ONE 7 (10): e46639. DOI:10.1371/journal.pone.0046639

Shi Q, Liu GH, Yan HQ, Zhang HL. 2012. Black Disease (Terpios hoshinota): A Probable Cause for the Rapid Coral Mortality at the Northern Reef of Yongxing Island in the South China Sea. Ambio 41: 446-455.

Soong K, Yang SL, Chen CA. 2009. A novel dispersal mechanism of a coral-threatening sponge, Terpios hoshinota (Suberitidae, Porifera) 
Suharsono. 2008. Jenis-Jenis Karang di Indonesia. Puslit Oseanografi LIPI Press, Jakarta.

Spalding MD, Grenfell AM. 1997. New estimates of global and regional coral reef areas. Coral Reefs 16 (4): 225-230.

Spalding MD, Corinna R, Edmund G. 2001. World Atlas of Coral Reefs. University of California Press and UNEP/WCMC, Berkeley.

Tamura K, Stecher G, Peterson D, Filipski A, Kumar S. 2013. MEGA6: Molecular Evolutionary Genetics Analysis version 6.0. Mol Biol Evol 33 (7): 1870-1874.

Tang SL, Hong MJ, Liao MH, Jane WN, Chiang PW, Chen CB, Chen CA. 2011. Bacteria associated with an encrusting sponge (Terpios hoshinota) and the corals partially covered by the sponge. Environ Microbiol 13 (5): 1179-1191.

Teruya T, Nakagawa S, Koyama T, Arimoto H, Kita M, Uemura D. 2004 Nakiterpiosin and nakiterpiosinone, novel cytotoxic C-nor-Dhomosteroids from Okinawan sponge Terpios hoshinota. Tetrahedron 60: 6989-6993.

Thakur NL, Müller WEG. 2004. Biotechnological potential of marine sponges. Curr Sci: 86 (11): 1506-1512.

van der Ent E, Hoeksema BW, de Voogd NJ. 2016. Abundance and genetic variation of the coral-killing cyanobacteriosponge Terpios hoshinota in the Spermonde Archipelago, SW Sulawesi, Indonesia. J Mar Biol Assoc UK 96 (2): 453-463.

Wang JT, Hirose E, Chen YY, Meng PJ, Sune YH, Hsu CM, Wei KY, Chen CA. 2012. Diverse interaction between corals and the coralkilling sponge, Terpios hoshinota (Suberitidae: Hadromerida). Zool Stud 51(2): 150-159.

Wang JT, Hsu CM, Kuo CY, Meng PJ, Kao SJ, Chen AC. 2015. Physiological our performance at the morphologically-transformed edge of the cyanobacteriosponge Terpios hoshinota (Suberitidae: Hadromerida) when confronting opponent corals. PLoS ONE 10 (6): e0131509. DOI:10.1371/journal.pone.013509.

Wilkinson CR. 2004. Status of Coral Reefs of The World: 2004. Australian Institute of Marine Science, Australia.

Wilkinson CR. 2008. Status of Coral Reefs of The World: 2008. Australian Institute of Marine Science, Australia.

Yang SY, Chen HJ, Ho MJ, Chen YJ, Huang YY, Chow WS, Tang SL, Jeng MS, Chen CA. 2018. Outbreak of coral-killing cyanobacteriosponge, Terpios hoshinota, in Taiping Island (Itu Aba), Spratlys, South China Sea. Bull Mar Sci 94 (4): 1543-1544. 